\title{
A Review of Psychological Contract
}

\author{
Jian Li, Liangtie Dai \\ Jinan University, Guangzhou, China \\ Email: lijian1991sky@163.com
}

Received 25 August 2015; accepted 19 September 2015; published 22 September 2015

Copyright (C 2015 by authors and Scientific Research Publishing Inc.

This work is licensed under the Creative Commons Attribution International License (CC BY).

http://creativecommons.org/licenses/by/4.0/

(c) (i) Open Access

\begin{abstract}
This thesis starts from the fuzzy sets and related concepts of Psychological Contract which includes its notion, content, dimension, formation and violation of the Psychological Contract. The writer puts forward some opinions on the basis of previous research achievements by native and foreign scholars. At the same time, the drawbacks, research focal points and trends in the future are pointed out.
\end{abstract}

\section{Keywords}

\section{Psychological Contract, Dimension, Formation, Violation}

\section{Introduction}

With the competition of globalization, many policies including process re-engineering, strategic alliance, outsourcing, merger and reorganization and flat organization emerged, which made organizations may be less willing to meet staffs' commitments. So the organizations had to renegotiate and change some terms of the original employment agreement (Chen, Ling, \& Fang, 2001). This led to the business redundancy This made the layoffs become a common phenomenon in the world. Traditionally, if employees could be loyalty and work hard, they would get the promise of long-term job security and professional development. Now, this might not be effective longer (Guest, 1995). It could decrease employees’ satisfaction and job performance, destroyed their loyalty, increased the acts of hostility and even lost core employees. Managers of enterprises were bothering with these problems such as employees' attitudes and behaviors. So psychological contract-the perception and understanding of the exchange relationship between the employee and the organization, increasingly gained popular attention from academic and business world (Herriot \& Pemberton, 1995), and it had become the focus of overseas human resources management over the last decades. Based on research results of the psychological contract abroad, this article would summarize and simply evaluated them. Finally, the research focal point and direction in the future were pointed out. 


\section{The Notion of the Contract}

The concept of the psychological contract was first put forward by Argyris, a famous American behavioral scientist, in his book Understanding of Organizational Behavior, he talked about the hidden and informal tacit agreement between the foreman and workers. Argyris just proposed the conception, but no more specific definition (Argyris, 1960). Then, analyzing information from the face-to-face talk with 847 employees in a case study in a public institution. Levinson defined psychological contract as an unwritten contract that literally means a mental contract between employer and employees without letter contained expectations (Levinson et al., 1962). It was used to emphasize an internal and hidden expectations which preceded the establishment of the relationship. Schein defined psychological contract as a set of unwritten expectations among organization members, and he divided psychological contract into two levels: individuals and organizations. Later, Kotter further theorized that psychological contract was a hidden contract among organizations and individuals including about what they were due, what they deserved. These notions above show that the psychological contract is a kind of subjective understanding on the relationship and what they were due among employee and employers. These notions follow the early basic views and the two-way expectations of the organizations and individuals were emphasized. Therefore, the scholars who held the view of two-way expectations were called Classical School, in the meantime, all the notions in accordance with two-way expectations were called broad definition of the psychological contract.

Corresponding to the broad definition is narrow conception of the psychological contract. It was Rousseau, an American scholar, who first put forward it, and she redefined the psychological contract as a kind of understanding or faith about mutual responsibility between employees and employer. Later, Robinson pointed out that this kind of faith is the promise, understanding and perception on exchange relationship (Robinson, Kraatz, \& Rousseau, 1994).

Between employees' contribution (hard-work, ability, loyalty, etc.) and incentives given by the employer (pay, promotion, job security, etc.). This conception was further identified by Morrison. He pointed out that the psychological contract was usually defined as a set of faiths was held by employees about mutual responsibilities. These faiths were based on making sense of promise, while they might not be known by the organization or its agent. So, scholars who held the same view of one-way expectations as Rousseau were called Rousseau School.

In general, there exist two different definitions above of the psychological contract. The broad definition is the understanding about mutual responsibilities in exchange relationship among employer and employees subjectively in accordance of all kinds of promises whether written, spoken or under the regulations of organization; while the narrow definition is a set of faiths were generated under the understanding of organization policy, practice and culture or the encouragement by agents' promises, sometimes the agents might not be conscious. The classical school though there were two subjects in the psychological contract, but it precisely disturbed the empirical research because of the non-uniqueness of the psychological contract which caused by two different subjects of two different views of expectations. Then the classic school redefined the conception, found a good solution in the empirical research and they gained more researchers` recognition. At present, most of empirical researches were based on the narrow definition of the psychological contract.

\section{The Content and Dimension of Psychological Contract}

Further study of the psychological contract was conducted since the conception was proposed in 1960s. With the emergence of a global knowledge economy, employment relationship was changed in late 1980s and early 1990s, this situation become more clear (Herriot, Manning, \& Kidd, 1997).

In 1990, Rousseau tested 129 MBA graduates on their psychological contracts, she was the first person who conducts this issue in the empirical research (Rousseau, 1990). The study found that the employer had seven responsibilities in the employees' psychological contract: 1) promotion; 2) high reward; 3) performance rewards; 4) training; 5) long-term job security; 6) career development; 7) HR support. The employees had eight responsibilities in the employees' psychological contract: 1) working overtime; 2) loyalty; 3) voluntarily engages in the work beyond the call of duty; 4) notify your quit in advance; 5) accept Internal Work Adjustment; 6) do not help rivals; 7) disclose no secret; 8) remaining with the company for at least two years.

In 1997, using the method of critical incidents technique and stratified proportional sampling, Herriot and Manning did research on the psychological contract which belonged to 184 managers and 184 employees in all walks of life. They found that there existed 12 employers' responsibilities in these contracts: 1) training; 2) fair- 
ness; 3) care; 4) negotiation; 5) trust; 6) kindness; 7) understanding; 8) safety; 9) perseverance; 10) pay; 11) welfare; 12) stable jobs. These contracts also showed seven employees' responsibilities: 1) punctuality; 2) working hard; 3) honesty; 4) loyalty; 5) to protect the company’s assets; 6) to show organizational image; 7) mutual assistance. When it comes to organizational obligation, employers and the employees are different in six aspects, safety, pay and stability. These employees focus on safety, understanding, welfare, kindness, pay and stability, while employers focus on kindness, understanding and welfare. When it comes to employees' responsibility, they hold different opinions in loyalty, protecting the companies' assets and showing organizational image. These employees focus on protecting the company's assets and showing organizational image, while employers focus on loyalty. It's so rare that psychological contract was discussed fully from the perspective and responsibilities of both sides.

Anderson thought the specific contents were so complicated that we could not list them all (Aanerson \& Schalk, 1998). In order to know the basis of psychological contract, many scholars analyzed the dimension. There were two kinds of theories about the dimension of psychological contract: two-dimensional structure and three-dimensional structure.

After analyzing seven employers' responsibilities and eight employees' responsibilities of the psychological contract of 129 MBA graduates by way of Canonical Correlation Analysis. Rousseau got two pairs of typical variables. The first pair of variable showed employees were given high reward, performance rewards, training and career development by the organization at the expense of working overtime and working beyond duty (Rousseau, 2001). This kind of contract based on economic transactions was called transactional contract; the second pair of variable showed employees were given long-term job security by the organization at the expense of loyalty, accepting internal work adjustment and long-term working. This kind of contract based on emotional transactions was called relational contract. Millward proved that there exited transactional contract and relational contract throughout analyzing the scales (Millward \& Hopkins, 1998). The "transaction—relative dimension" were supported by empirical evidence at some level in western countries especially in America and Britain. Many researchers discussed relevant issues about the psychological contract on the basis of "transaction—relative dimension”.

Kickul and Lester thought the two-dimensional structure includes extrinsic contract and intrinsic contract (Kickul \& Lester, 2001). After analyzing 11 employers' responsibilities from the psychological contract of 246 MBA students, Kickul extracted two factors: extrinsic contract and intrinsic contract. Extrinsic contract involved employers' promises to employees' finished work such as flexible working hours, a safe work environment and competitive salary and bonus. Intrinsic contract involved employers' promises to the nature of the work such as self-selection in jobs, making their own decisions, self-control, engaging in all kinds of challenging work, provide support from organization, decision-making participation, giving chances of development and so on.

Besides, scholars in mainland China, including Chen Jiazhou, Ling Wenquan and Fang Liluo also did a theory study and empirical study on the psychological contract between Chinese employees and organizations, and they found two factors called realistic obligation and developmental obligation (Chen, Ling, \& Fang, 2003). The organization and employee responsibility in employees' psychological contract all consists of two dimensions, that is real responsibility and development responsibility. All theories above belong to a two-dimensional structure. In fact, there are many theories about the three-dimensional structure.

Rousseau and Tijorimala proposed that three dimensions constituted the psychological contract through their empirical study (Rousseau \& Tijioriwala, 1996). They were transaction dimension, relative dimension and team members dimension. Transaction dimension means the organization gives economic benefits to employers and employers have to finish their tasks. Relation dimension means that both the organization and employees focus on a stable, bilateral, long-term relationship in the future which can promote their development. Team members dimension means that both the organization and employees focus on social support and human relations. Lee and Tinsley also thought transaction dimension, relative dimension and team members dimension constituted the employees' psychological contract.

$\mathrm{Li}$ Yuan found that three dimensions constituted the Chinese employees' psychological contract. They were normative responsibility, interpersonal responsibility and developing responsibility. Normative responsibility means the organization gives economic benefits to employers and employees have to finish their tasks under the premise of rules; interpersonal responsibility means that the organization gives social environment and human concern to employers and employees have to build a good social environment for employers; developing responsibility means that the organization provide more development for employers and employees are willing to work 
harder.

So, there is no unified statement about the dimension of the psychological contract. With the development of times and society, people's ideas and psychological states changed a lot. As a result, different time had different results.

\section{The Formation of Psychological Contract}

At present, the research on the formation of the psychological contract is rare. Dunahee and Wangler thought there were three factors influenced the formation and maintenance of psychological contract (Dunahee \& Wangler, 1974). The first factor is pre-employment negotiation, which is the basis of formation of the psychological contract. The second factor is the redefinition of psychological contract at work. It's a very important way for employees to communicate with their directors for the purpose of understandably. The meaning of a contract or making it clear. The third factor is to keep fairness and dynamic balance. When the organization or the individuals found it was an unfair contract, they will take action unilaterally to bring it into balance. So they tried to find the "correct the loop” of the contact to maintain their senses of fairness. When it couldn't adjust or adjusted too fast, there will be one side quitting.

Rousseau thought there were four stages in the formation of the psychological contract (Rousseau, 2003). They were pre-employment, early socialization, recruitment and later experiences. Different stage had different behavior and belief. It also had different influence on the formation of the psychological contract. Turner and Feldman thought the employees' expectation of psychological contract consists of three thins. The first one is the specific promise given by agents; the second one is their perception of organizational culture and their practice; the third one is their expectations to the organization movement (Turnley \& Feldman, 1999).

Chinese scholars Cao Weilin and Chen Wenjiang also put forward a model of the formation of the psychological contract. This model is a dynamic and relatively closed circulatory system. There were 4 stages in the process of formation. The first stage is to choose and interpret both sides information; the second stage is to expect to have contract; the third stage is that psychological offer and counter offer were formed by both sides through mental hints; the last stage is making promises which is to receive offer and to come to terms regarding the contract. The conversations between both sides all of implied and indirect mental hints or other methods through this process. Once the environment and their situation were changed, it will go on to the next step.

\section{The Breach of Psychological Contract}

There are two classic models of psychological contract breach. One is the model of the formation of psychological contract breach which proposed by Morrison (Morrison \& Robinson, 1997), another one is discrepancy model proposed by Turnlry. Morrison and Robinson summarized research results in the past and they thought there must be a complicated explanation, if cognitive evaluation and emotional responses generated when the psychological contract were not fulfilled. They proposed a development model of psychological contract breach. They thought employees could not experience psychological contract breach until they went through three stages: making promises but fail to fulfill, contract breach and violation. Every stage was influenced by different cognition process. They thought a breach and violation are two totally different concepts. We can't mix them up as it had in the past. The beach we can experience means that employees find the organization doesn't fulfill its obligations as the psychological contract; while the violation means that employees show their strong mood for the organization doesn't fulfill its obligations. Morrison and Robinson clarified the notion of psychological contract breach which ended the chaos in breach research. It was a great breakthrough in breach research which gained approving by the experts.

The second one is a discrepancy model proposed by Turnley. It gives us detailed descriptions of the three factors of promoting the violation and breach (Turnley \& Feldman, 1999). They are the source of employees' expectations, the specific reasons for the breach of psychological contract and the nature of the discrepancy; and they also thought of employees' behaviors were influenced by individual difference, organizational practices and the feature of the labour market. They considered that the reason for breach and violation of psychological contract was quite complicated, and the time when employees show their strong negative emotions was not certain, it depends on the situation. It is a pity that when they discussing the employee behaviors responded to violation and rupture of the psychological contract, they didn't distinguish violation from rupture. They divided the employees' behavior after psychological contract into four types: quit, lowering the performance of the du- 
ties, lowering the performance beyond the duties and showing antisocial behavior on the basis of explanations of Morrison and Robinson.

\section{Limitations and Future Research Directions}

Although there are plenty of research results on the psychological contract, it also has some problems when sorting the research results of foreign experts and scholars.

Firstly, the analytical and measuring tools are relatively lacked. There are no effective analytical and measuring tools yet to study the content, dimension and types of psychological contract.

Secondly, past studies focus more on local problems such as the notion of psychological or breach, but there is short of studies on the reason, nature, results and systems research on formation of psychological contract, which restricts application value of Psychological Contract Theory.

Thirdly, past studies focus on the contract between organization and employees, but psychological contract between the organization and managers are ignored, especially the key talents in an organization. It is quite important to maintain and improve the relationship between organizations and managers.

The future research should base on the following:

Firstly, the future study should pay more attention to the complementary and common development of contractual economy, and expand the scope of the study to build a multilevel and grade separation pattern.

Secondly, the future study should think the dynamic process of psychological contract systematically, and try to build a complete system to further clarify its framework under the interaction between theoretical and empirical research, fully display its greater potential value.

Thirdly, future researches should develop effective measurement tools on bilateral responsibilities. Much empirical research mostly bases on a narrow and one-way psychological contract. In fact, psychological contract is not a bilateral right-duty relation, but also the result of the interaction of both sides. If we can study the mutually accepted responsibilities, we will discover why the psychological contract can influence attitudes and behaviors. So, in the future, we are looking forward to developing more effective measuring tools of two-way responsibility.

\section{References}

Aanerson, N., \& Schalk, R. (1998). The Psychological Contract in Retrospect and Prospect. Journal of Organizational Behavior, 19, 637-647.

Argyris (1960). Understanding Organizational Behavior. London: Tavistock Publications.

Chen, J. Z., Ling, W. Q., \& Fang, L. L. (2001). Psychological Contract in Organization. Journal of Management Sciences in China, 4, 74-78.

Chen, J. Z., Ling, W. Q., \& Fang, L. L. (2003). Structure of Psychological Contract between Corporation and Employees. Chinese Journal of Psychology, 35, 404-410.

Dunahee, M. H., \& Wangler, L. A. (1974). The Psychological Contract: A Conceptual Structure for Management/Employee Relation. Personnel Journal, 7, 518-526.

Guest, E. D. (1998). Is the Psychological Contract worth Taking Seriously? Journal of Organizational Behavior, 19, 649664. http://dx.doi.org/10.1002/(SICI)1099-1379(1998)19:1+<649::AID-JOB970>3.0.CO;2-T

Herriot, P., Manning, W. E. G., \& Kidd, J. M. (1997). The Content of the Psychological Contract. British Journal of Management, 8, 151-162. http://dx.doi.org/10.1111/1467-8551.0047

Herriot, P., \& Pemberton, C. (1995). New Deals. The Revolution in Managerial Careers. Chicester: John Wiley \& Sons.

Kickul, J., \& Lester, S. W. (2001). Broken Promises: Equity Sensitivity as a Moderator Between Psychological Contract Breach and Employee Attitudes and Behavior. Journal of Business and Psychology, 16, 191-217. http://dx.doi.org/10.1023/A:1011105132252

Levinson, H., Price, C. R., Munden, K. J., Mandl, H. J., \& Solley, C. M. (1962). Men, Management and Mental Health. Cambridge: Harvard University Press. http://dx.doi.org/10.4159/harvard.9780674424746

Millward, L. J., \& Hopkins, L. J. (1998). Psychological Contracts, Organizational and Job Commitment. Journal of Applied Social Psychology, 28, 1530-1556. http://dx.doi.org/10.1111/j.1559-1816.1998.tb01689.x

Morrison, E. W., \& Robinson, S. L. (1997). When Employees Feel Betrayed: A Model of How Psychological Contract Violation Develops. Academy of Management Review, 22, 226-256.

Rousseau, D. M. (1990). New Hire Perspectives of Their Own and Their Employers Obligations: A Study of Psychological 
Contracts. Journal of Organizational Behavior, 11, 389-401. http://dx.doi.org/10.1002/job.4030110506

Robinson, S. L., Kraatz, M. S., \& Rousseau, D. M. (1994). Changing Obligations and the Psychological Contract: A Longitudinal Study. Academy of Management Journal, 37, 137-152. http://dx.doi.org/10.2307/256773

Rousseau, D. M. (2003). Extending the Psychology of the Psychological Contract: A Reply to Putting Psychology Back into Psychological Contracts. Journal of Management Inquiry, 12, 229-238. http://dx.doi.org/10.1177/1056492603256339

Rousseau, D. M., \& Tijioriwala (1996). Perceived Legitimacy \& Unilateral Contract Change: It Takes a Good Reason to Change a Psychological Contract. Proceedings of the Symposium at the SIOP Meetings, San Diago, 1996.

Rousseau, D. M. (2001). Schema, Promise and Mutuality: The Building Blocks of the Psychological Contract. Journal of Occupational and Organizational Psychology, 74, 511-542. http://dx.doi.org/10.1348/096317901167505

Turnley, W. H., \& Feldman, D. C. (1999). The Impact of Psychological Contract Violations on Exit, Voice, Loyalty, and Neglect. Human Relations, 52, 895-922. http://dx.doi.org/10.1177/001872679905200703

Turnley, W. H., \& Feldman, D. C. (1999). A Discrepancy Model of Psychological Contract Violations. Human Resource Management Review, 9, 367-386. http://dx.doi.org/10.1016/S1053-4822(99)00025-X 